
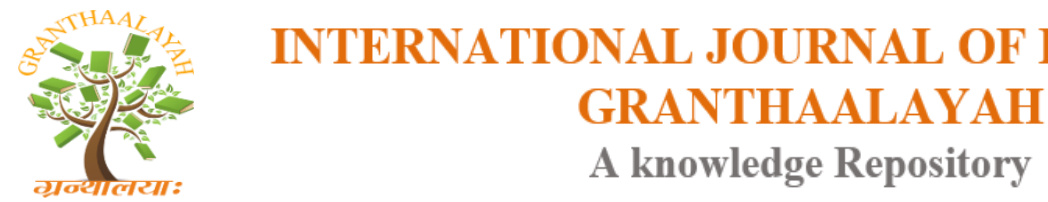

Management

\title{
FINANCIAL STUDY OF AN INVESTMENT PROJECT IN ALGERIA: CREATION OF A COMPANY WITHIN THE FRAMEWORK OF THE NATIONAL FUNDSUPPORT FOR YOUTH EMPLOYMENT (FNSEJ)
}

\author{
Dr Lyes OUABDESSELAM *1 \\ ${ }^{*}$ Searcher \& Member of the Board of Directors / Center for Scientific and Technical Research \\ (CRAPC), Tipaza, Algeria
}

DOI: https://doi.org/10.29121/granthaalayah.v5.i5.2017.1832

\begin{abstract}
This article proposes a financial study of a project to create a commercial enterprise through the scheme proposed by the National Agency for Youth Employment Support (ANSEJ). The company is a testing and analysis laboratory. In this study we have prepared a complete financial package and we have budgeted this project over the entire amortization period of the investment credit in accordance with the timetable set by the support system for young entrepreneurs to set up a business in Algeria. This work provides factual information to young entrepreneurs to assist them in making decisions about the implementation of similar projects.
\end{abstract}

Keywords: Financial Study; Business Creation; FNSEJ, Young Entrepreneur; Algeria.

Cite This Article: Dr Lyes OUABDESSELAM. (2017). "FINANCIAL STUDY OF AN INVESTMENT PROJECT IN ALGERIA: CREATION OF A COMPANY WITHIN THE FRAMEWORK OF THE NATIONAL FUNDSUPPORT FOR YOUTH EMPLOYMENT (FNSEJ)." International Journal of Research - Granthaalayah, 5(5), 1-7. https://doi.org/10.29121/granthaalayah.v5.i5.2017.1832.

\section{Introduction}

Thanks to favorable economic conditions in Algeria following the surge in hydrocarbon prices between 2001 and 2015, the State was able to adopt a policy of economic recovery and support for growth, especially for the promotion of SMEs / SMIs , Central actor in any economy [1]. This policy had different objectives, in particular the safeguarding, strengthening and modernization of SMEs and encouraging the creation of new businesses. SMEs have undergone a new dynamic thanks to the new SME orientation ${ }^{1}$ laws whose objective is to promote entrepreneurship, notably by the significant reduction of taxes, tax charges and social charges, as

\footnotetext{
${ }^{1}$ Such as Law No 1-18 of 12/12/2001: it includes the policy of State aid to SMEs; Establish administrative facilitation measures; Provides for the establishment of a guarantee fund for loans granted by banks to SMEs and the setting up of a national committee for the promotion of subcontracting
} 
well as a relaxation of formalities Administrative measures for business start-ups. Several mechanisms have been put in place by the State to facilitate the creation of business. These mechanisms fall within the framework of the economic recovery program established in 2003 for an amount of 55 million Dollars. For example, new financial instruments have been made available to SMEs, such as credit guarantees specific to innovative business lines; Restructuring credits: long-term financing for the purchase of equipment, equipment and real estate, to strengthen their industrial structure; Credit for business stability, to improve their strategic functions (production, commercialization, technological development) and mitigate the effects of structural reforms or natural disasters [2]. In the context of the liberalization of the world economy, programs to promote and make the economic fabric competitive have become a priority. To this end, the public authorities have put in place a strategy to support companies whose objective is to help them in their modernization and competitiveness efforts. It is the MEDA I / SME upgrading program (2003-2006) extended until 2007 and the MEDA II program in 2008, as well as the program to support the development of SMEs in Algeria [3]. The modernization of industrial facilities with the assistance of UNDP / UNIDO and the creation of a fund to promote industrial competitiveness; From the creation of various support institutions and special funds to support investment, promotion of industrial competitiveness, partnership and credit guarantees for SMEs. These various programs come from different ministries (Ministry of Commerce, Industry, Ministry of Small and Medium Enterprises and Crafts, etc.). Consequently, we note the plurality of structures for the creation, support, financing or promotion of SMEs, which can be summarized in the table below.

Table 1: Organizations involved in the promotion and support of SMEs.

\begin{tabular}{|l|c|}
\hline \multicolumn{1}{|c|}{ Organismes Assistance Committee for the } & \multicolumn{1}{c|}{ Date de création / objectifs } \\
\hline $\begin{array}{l}\text { The } \\
\text { Localization and Promotion of Investments } \\
\text { (CALPI). }\end{array}$ & Created in 1993 \\
\hline $\begin{array}{l}\text { The Agency for the Promotion and Support of } \\
\text { Investment (APSI). }\end{array}$ & Created in 1994 \\
\hline The Social Development Agency (ADS). & Created in 1994 in 1996 \\
\hline $\begin{array}{l}\text { The National Agency for the Support of Youth } \\
\text { Employment (ANSEJ). }\end{array}$ & Created in 2001 \\
\hline $\begin{array}{l}\text { The National Agency for the Development of } \\
\text { Investment (ANDI). }\end{array}$ & Created in 2004 \\
\hline $\begin{array}{l}\text { The National Agency for Microcredits } \\
\text { Management (ANGEM). }\end{array}$ & Created in 2004. \\
\hline $\begin{array}{l}\text { The National Unemployment Insurance Fund } \\
\text { (CNAC). }\end{array}$ & $\begin{array}{l}\text { Created in 11/11/2002. } \\
\text { Its objective is to guarantee investments in the } \\
\text { SME sector in terms of business start-ups, } \\
\text { renovation of equipment and business } \\
\text { expansion. }\end{array}$ \\
\hline $\begin{array}{l}\text { The SME Credit Guarantee Fund (FGAR). } \\
\text { is consultation. }\end{array}$ \\
\hline $\begin{array}{l}\text { The National Advisory Council for SMEs } \\
\text { (CNC-PME) }\end{array}$ & $\begin{array}{l}\text { Established in 2003 and whose main function } \\
\text { The SME Investment Credit Guarantee Fund }\end{array}$ \\
\begin{tabular}{l} 
Implementation decided in 2004; is \\
\hline
\end{tabular}
\end{tabular}




\begin{tabular}{|c|c|}
\hline (CGCI-PME) & $\begin{array}{l}\text { organization that has come to reinforce the } \\
\text { FGAR. }\end{array}$ \\
\hline $\begin{array}{l}\text { The National Agency for the Development of } \\
\text { SMEs (AND-PME) }\end{array}$ & $\begin{array}{l}\text { Created in } 2005 \text {. Its main mission is the } \\
\text { implementation of the upgrade program. The } \\
\text { agency reviews requests from companies } \\
\text { wishing to benefit from the upgrading program } \\
\text { and awarding incentives for upgrading. }\end{array}$ \\
\hline Business incubators & $\begin{array}{l}\text { These are structures for welcoming and } \\
\text { developing nascent enterprises. They were } \\
\text { fourteen (14) in the year } 2006 \text { with projects to } \\
\text { create new nurseries in the High Plateaux and } \\
\text { the South. }\end{array}$ \\
\hline $\begin{array}{l}\text { Business incubators in collaboration with the } \\
\text { MESRS et l'ANRDT }\end{array}$ & $\begin{array}{l}\text { Created at the level of the main university } \\
\text { poles. }\end{array}$ \\
\hline The Directions of wilaya & They are sources of information. \\
\hline Facilitation centers & $\begin{array}{l}\text { It is the structures of support, supervision and } \\
\text { support and guidance of investors carrying } \\
\text { projects. }\end{array}$ \\
\hline $\begin{array}{l}\text { Department for Monitoring and Information } \\
\text { Systems on SMEs and another for the } \\
\text { Promotion of subcontracting (ANDPME). }\end{array}$ & $\begin{array}{l}\text { Creation project in } 2017 \text {. } \\
\text { - The first department functioning as an } \\
\text { observatory of the SME; These two } \\
\text { departments will, a priori, reinforce and } \\
\text { capitalize the efforts of the ANDPME. } \\
\text { - The facilitation centers and business } \\
\text { incubators will be attached to ANDPME to } \\
\text { be set up as Support and Counseling } \\
\text { Centers for SMEs and will consequently } \\
\text { constitute the dismemberment of the } \\
\text { agency at the local level [4]. }\end{array}$ \\
\hline
\end{tabular}

\section{Material and Methods of Calculation}

In our study, the calculations were carried out by Microsoft Office Excel version 2016 software according to the modalities fixed by regulation relative to the employment aid scheme for young people in Algeria. The taxes and charges applied in this study are those in force prior to 01/01/2017. The credit of the bank without interest is amortized over a period of eight years (8 years) [5]; the reimbursement of the deductible sum of the FNSEJ does not begin until the credit of the bank has been repaid, ie at the eighth year (08 years) after the actual start of the company's business [6].

${ }^{2}$ Communiqué from the Preliminary Draft of the Ministry of Industry and Mining; 2017. 


\section{Financial Mounting of the Project}

\subsection{Financial study}

In our study, all equipment has been ordered from local suppliers and the tax charge assumed in our calculations is that applicable until 31/12/2016. We summarize the cost of the project in All taxes included (TTC) in the financial package in the following.

Table 2: Financial mounting of the project

\begin{tabular}{ll}
\hline rubric & Total Cost (in DA) \\
\hline Preliminary costs & 367207,25 \\
Guarantee fund contribution $*$ & 138560,42 \\
insurance & 178646,83 \\
Additional costs ${ }^{*}$ & 50000,00 \\
\hline Equipment & 7159171,50 \\
Local Equipment & 7103171,50 \\
Imported equipment & 0,00 \\
Installation costs & 30000,00 \\
Shipping & 26000,00 \\
\hline Rolling stock & $\mathbf{1 5 7 9 0 0 0 , 0 0}$ \\
\hline Other Taxes & $\mathbf{1 2 0 5 0 0 , 0 0}$ \\
\hline Accommodation & $\mathbf{2 0 0 0 0 0 , 0 0}$ \\
\hline Office furniture & $\mathbf{1 8 8 5 6 0 , 6 7}$ \\
\hline TOTAL PROJECT (TTC) & $\mathbf{9 4 2 5} \mathbf{8 7 9 , 0 0}$ \\
\hline
\end{tabular}

* These costs are borne by the State as part of the facilitation granted to young entrepreneurs. So we did not take care of them in the overall cost of the project.

\subsection{Project financing structure}

The financing of the overall cost of the project is provided by each party, namely, the contractor, the bank and the ANSEJ. Referring to the regulatory framework governing co-financing by the ANSEJ / Banque, the contribution of the contractor would be in the order of 02\%, ANSEG and the Bank will contribute $28 \%, 70 \%$ of the Sum of the project [7]. Below is a table with a structure for inputs from stakeholders to projects.

Table 3: Level of inputs from project stakeholders

\begin{tabular}{llll}
\hline rubric & Participation rate & Initial Amount (in DA) & $\begin{array}{l}\text { Actual Amount } \\
\text { (In DA) }\end{array}$ \\
\hline Personal contribution & $02 \%$ & 188517,58 & 188518,00 \\
FNSEJ contribution & $28 \%$ & 2639246,12 & 2639246,00 \\
Bank financing & $70 \%$ & 6598115,88 & 6598115,00 \\
\hline TOTAL (en TTC) & $\mathbf{1 0 0 \%}$ & $\mathbf{9 4 2 5} \mathbf{8 7 9 , 5 8}$ & $\mathbf{9 4 2 5 8 7 9 , 0 0}$ \\
\hline
\end{tabular}




\subsection{Amortization of Investment Credit}

\subsubsection{Bank Credit}

The credit of the bank is amortized over a period of eight years ( 8 years) with a reduction of around $100 \%$ interest rate over the life of the loan with possibility of extension [5].

Table 4: Amortization of bank credit

\begin{tabular}{|c|c|c|c|}
\hline Item & $\begin{array}{l}\text { Amount to } \\
\text { be paid }\end{array}$ & $\begin{array}{l}\text { Amount } \\
\text { remaining to } \\
\text { be refunded }\end{array}$ & $\begin{array}{l}\text { membership } \\
\text { fee } \mathrm{FG}^{3}\end{array}$ \\
\hline Year 01 & 0 & 6598115,08 & 23093,4 \\
\hline Year 02 & 0 & 6598115,08 & 23093,4 \\
\hline Year 03 & 0 & 6598115,08 & 23093,4 \\
\hline Year 04 & 1319623,00 & 5278492,08 & 23093,4 \\
\hline Year 05 & 1319623,02 & 3958869,06 & 18474,72 \\
\hline Year 06 & 1319623,02 & 2639246,04 & 13856,04 \\
\hline Year 07 & 1319623,02 & 1319623,02 & 9237,36 \\
\hline Year 08 & 1319623,02 & 0 & 4618,68 \\
\hline Total & 6598115,10 & Total & 0,40 \\
\hline
\end{tabular}

Ps: ${ }^{3}$ The Fund of Guarantee (FG) is entirely supported by the State, the calculation of the tranches of payment is carried out in accordance with Executive Decree $N \circ 200-98$ of 09/06/1998 creating the fund of collective subsidy to constitute a fund Guarantee to cover the inherent danger to loans granted to young entrepreneurs.

\subsubsection{National Youth Employment Support Fund (FNSEJ)}

The repayment of the deductible sum of the FNSEJ does not begin until the credit is repaid without interest of the bank that is to say at the eighth year (08 year) after the actual start of the activity of the company and this Regardless of its turnover [6]. The credit of the ANSEJ is amortized over a period of five years (05 years). Payment will be made in six-monthly installments in accordance with the regulations governing the employment support scheme for young people [8]. Attached is a detailed amortization table of the ANSEJ credit of the project studied.

Table 5: Amortization of FNSEJ credit

\begin{tabular}{lll}
\hline Item & Amount to be paid & Amount to be refunded \\
\hline Year 08 & 263924,6 & 2639246,00 \\
\hline Year 09 & 263924,6 & 2375321,4 \\
Year $09_{\mathbf{b}}$ & 263924,6 & 2111396,8 \\
\hline Year $10_{\mathbf{a}}$ & 263924,6 & 1847472,2 \\
Year $10_{\mathbf{b}}$ & 263924,6 & 1583547,6 \\
\hline Year $11_{\mathbf{a}}$ & 263924,6 & 1319623,00 \\
Year $11_{\mathbf{b}}$ & 263924,6 & 1055698,4 \\
\hline Year $12_{\mathbf{a}}$ & 263924,6 & 791773,8
\end{tabular}




\begin{tabular}{lll} 
& \multicolumn{1}{c}{$\begin{array}{c}\text { InfoBase Index IBI Factor 3.86 } \\
\text { Year 12 }\end{array}$} \\
\hline Year 13 & 263924,6 & 527849,2 \\
\hline TOTAL & 263924,6 & 263924,6 \\
\hline
\end{tabular}

a: $1^{\text {st }}$ Semester; b: $2^{\text {th }}$ Semester

\section{Discussions \& Conclusion}

We see that the state has made progress in improving the business climate and is working on a long-term strategy to transform the country's growth model in order to promote private sector activity and diversification of the economy placing the center of its strategy. This is shared by the International Monetary Fund (IMF) [9]. The facility offered by the ANSEJ exhibit largely explains the current number of small businesses and their weight in the national industrial fabric. Indeed, their number has increased sharply during the last decade, from 570838 in 2009 to 1014 075 in 2016, with the private sector accounting for more than two thirds [10]. Thanks to its support strategy, Algeria has moved from the 163th position in 2016 to the 159th place in 2017 in the area of business start-up [11]. The data show that $90 \%$ of existing SMEs belong to the category of micro-enterprises with fewer than 10 employees [10]. This financial study clearly shows the facilities granted to young entrepreneurs to encourage them to set up their own businesses in Algeria. This study should be appended to an opportunity study and a feasibility study in order to constitute a complete Business Plan which will constitute a valuable tool of help in the factual decision making for the launch or not of this project [12].

\section{References}

[1] ASSALA K.. (2006). "SMES IN ALGERIA: FROM CREATION TO GLOBALIZATION" COMMUNICATION IN THE INTERNATIONAL SYMPOSIUM "INTERNATIONALIZATION OF SMES AND THEIR IMPLICATIONS FOR ENTREPRENEURIAL STRATEGIES", 25-26 October 2006, Haute School of Management (HEG) Friborg, Switzerland.

[2] DAOUD S. (2006). "DEVELOPMENT OF SMALL AND MEDIUM-SIZED ENTERPRISES IN ALGERIA: POLICIES AND OBSTACLES", COMMUNICATION AT THE INTERNATIONAL SYMPOSIUM ON "GLOBALIZATION, INSTITUTIONS AND PRODUCTIVE SYSTEMS IN THE MAGHREB" 22 and 23 June 2006, Hammamet, Tunisia. Ministry of Small and Medium Enterprise and Handicrafts. Bulletin No. 17, December 2009.

[3] OUABDESSELAM L. and NOUI F. (2017). "THE ALGERIAN FAMILY BUSINESS AND THE UPGRADING PROGRAMS: APPROACH QUALITATIVE". International Journal of Research - Granthaalayah 5(4), 238-245. https://doi.org/10.5281/zenodo.571530

[4] Communicate from the Ministry of Industry and Mining. See the link next: http://www.commerce.gov.dz/actualites/ce-que-prevoit-le-projet-de-loi-sur-les-pme

[5] Executive Decree No. 253-13 of 02/07/2013 in addition to Executive Decree No. 297-96 of 08/09/1996 laying down the conditions and the level of granting of assistance to young promoters.

[6] Executive Decree No. 295-96 of 08/09/1996 laying down the terms and conditions for the management of the Special Fund No. 087-302 entitled "National Fund for the Support of Youth Employment".

[7] Executive Decree No. 290-03 of 06/09/2003 setting the conditions and the level of support for projects of young entrepreneurs.

[8] Presidential Decree No. 234-96 of 02/07/1996 on support for the employment of young people. 
[9] Report of the International Monetary Fund (IMF) of 20 March 2017. Available on the following link: http://www.imf.org/fr/news/articles/2017/03/20/pr1790-algeria-imf-staff-completes-2017article-iv-mission (Last Viewed on 21/03/2017).

[10] Statistical bulletin of the Ministry of Industry and Mines, No. 29, December 2017. Available on the following link: http://www.mdipi.gov.dz/?Bulletin-de-veille-statistique (Last Viewed on 02/01/2017).

[11] Report 'DOING BUSINESS 2016' drafted by the World Bank. Available on the following link: http://francais.doingbusiness.org/data/exploreeconomies/algeria (Last Viewed on 01/04/2017).

[12] OUABDESSELAM L. and ATTATFA M.M. (2017), PROJECT TO LAUNCH A NEW AGRIFOOD PRODUCT "PIECES OF CHICKEN BREADED AND FROZEN", BookBoon.com Edition ltd, ISBN: 978-87-7681-487-8. London, Royaume Uni, 43 page. In press.

*Corresponding author.

E-mail address: ouabdesselam.lyes@yahoo.com 